\title{
A new multiplex real-time pcr assay to improve the diagnosis of shellfish regulated parasites of the genus marteilia and bonamia
}

\author{
Canier Lydie 1, ${ }^{*}$, Dubreuil Christine 1, Noyer Mathilde ${ }^{1}$, Serpin Delphine 1, Chollet Bruno ${ }^{1}$, \\ Garcia Celine ${ }^{1}$, Arzul Isabelle ${ }^{1}$
}

1 Ifremer, RBE-SG2M-LGPMM, Station de La Tremblade, Avenue de Mus de Loup, F-17390 La

Tremblade, France

* Corresponding author : Lydie Canier, email address : Lydie.Canier@ifremer.fr

\begin{abstract}
:
Aquaculture including shellfish production is an important food resource worldwide which is particularly vulnerable to infectious diseases. Marteilia refringens, Bonamia ostreae and Bonamia exitiosa are regulated protozoan parasites infecting flat oysters Ostrea edulis that are endemic in Europe. Although some PCR assays have been already developed for their detection, a formal validation to assess the performances of those tools is often lacking. In order to facilitate the diagnosis of flat oyster regulated diseases, we have developed and evaluated a new multiplex Taqman® PCR allowing the detection of both M. refringens and Bonamia sp. parasites in one step.
\end{abstract}

First part of this work consisted in assessing analytical sensitivity and specificity of the new PCR assay. Then, diagnostic performances were assessed by testing a panel of field samples with the new real-time PCR and currently recommended conventional PCR methods for the detection of M. refringens and Bonamia sp. Samples were collected from the main flat oyster production sites in France $(\mathrm{N}=386$ for $\mathrm{M}$. refringens and $\mathrm{N}=349$ for $\mathrm{B}$. ostreae). In the absence of gold standard, diagnostic sensitivity and specificity of the new PCR were estimated through Bayesian latent class analysis (DSe $87,2 \%$ and DSp $98,4 \%$ for the detection M. refringens, DSe $77,5 \%$ and DSp $98,4 \%$ for the detection of Bonamia sp.). Those results suggest equivalent performances for the detection of Bonamia sp. and an improved sensitivity for the detection of M. refringens compared to commonly used conventional protocols. Finally, the new PCR was evaluated in the context of an inter-laboratory comparison study including 17 European laboratories. Results revealed a very good reproducibility with a global accordance (intra-laboratory precision) $>96 \%$ and a global concordance (inter-laboratory precision) $>93 \%$ for both targets, demonstrating that this new tool is easily transferable to different laboratory settings.

This is the first assay designed to detect both Marteilia refringens and Bonamia sp. in a single step and it should allow reducing the number of analysis to monitor both diseases, and where relevant to demonstrate freedom from infection. 


\section{Highlights}

$\checkmark M$. refringens, B. ostreae and B. exitiosa are regulated parasites of flat oysters. $\rightarrow$ First validated PCR detecting all regulated pathogens of flat oysters in one step. Multiplex PCR performances similar or higher than currently recommended PCR assays. Represents a substantial improvement in time, resources and accuracy. Useful to monitors parasites prevalence or for demonstration of freedom.

Keywords : multiplex real-time PCR, Bonamia spp., Marteilia refringens, flat oysters, diagnostic accuracy study, Inter laboratory comparison 

Abbreviations
DSe: Diagnostic sensitivity
DSp: Diagnostic specificity
EURL : European Union Reference Laboratory
OIE: World Organization for Animal Health
PCR: Polymerase Chain Reaction
ILC: Inter Laboratory Comparison

Keywords : multiplex real-time PCR, Bonamia spp., Marteilia refringens, flat oysters, diagnostic accuracy study, Inter laboratory comparison

\section{INTRODUCTION}

Shellfish contribute to food security word wild and have an important function in the marine environment. Diseases are a major threat for these productions as well as wild populations. Marteiliosis and Bonamiosis are two diseases caused by protozoan parasites that have resulted in mass mortality events of flat oysters in Europe and in different parts of the world (Berthe et al., 2004; Cranfield et al., 2005; Hudson and Hill, 1991; Montes, 1990; Van Banning, 1991). Here after, Marteiliosis and Bonamiosis is used for infection with $M$. refringens, and with $B$. ostreae and $B$. exitiosa, respectively. 
Marteilia refringens belongs to the order Paramixida. It was first detected in France in the 60's associated with mortalities of European flat oysters Ostrea edulis (see Grizel et al., 1974) and since then has been observed in several other European countries. The parasite generally infects the epithelium of the digestive system (see Grizel et al., 1974). Death of $O$. edulis usually occurs during the second year after the initial infection in association with the sporulation of the parasite.

Marteilia refringens is also known to infect mussels Mytilus edulis and Mytilus galloprovincialis (see Tige and Rabouin, 1976; Villalba et al., 1993), although the induced disease is less severe than in flat oysters. However, whether Marteiliosis in mussels and in flat oysters is causes by the same parasite is not clear. Two distinct species were recognized: $M$. refringens infecting oysters and $M$. maurini infecting mussels (See Comps et al., 1981; Figueras and Montes, 1988; Le Roux et al. 2001). Further studies suggested that morphological and genomic differences between $M$. refringens and $M$. maurini were too low to consider them as separate species (Balseiro et al., 2007; Longshaw at al., 2001; Lopez-Flores et al., 2004), and both species were officially named $M$. refringens in 2007. Two types of $M$. refringens were then recognized: the O-type, more often detected in flat oysters, and the M-type more often detected in mussels ( $M$. refringens definition according to OIE Aquatic Manual, 2008-2019). More recently, a taxonomic study using high throughput sequencing suggested restoring the two separate species recognition (Kerr et al., 2018). Authors proposed to rename the M-type as Marteilia pararefringens (Kerr et al., 2018). In this study, the "O-type" and "M-type" nomenclature will be used. M. refringens has also been sporadically reported in other bivalve species such as clams Solen marginatus and Chamelea gallina (Lopez-Flores et al., 2008a; Lopez-Flores et al., 2008b), and the mussel Xenostrobus secures (Pascual et al., 2010). Other Marteilia species have been described in marine molluscs including $M$. sydneyi in Sydney rock oysters Saccostrea glomerata in Australia (Perkins and Wolf, 1976), M. cochillia in cockles Cerastoderma edule in Spain (Carrasco et al., 2013; Villalba et al., 2014), M. 
octospora in clams Solen marginatus (Ruiz et al., 2016), M. granula and M. tapetis in Manila clams Ruditapes phillipinarum from Japan (Itoh et al., 2014) and South Korea (Kang et al., 2019), respectively.

Bonamiosis is caused by parasites of the genus Bonamia which are small-size eukaryotes also called microcells belonging to the order Haplosporidia. Bonamia parasites mainly infect flat oysters of the genus Ostrea. They are intracellular parasites infecting hemocytes. Host death usually occurs concurrently to the highest intensity infection level. Bonamia ostreae was originally described in France (Ostrea edulis) in the 70's (See Pichot et al., 1981) and had quickly spread along the European coasts. Bonamia ostreae is also present in North America (Friedman et al., 1989) and in New Zealand since 2015 (Lane et al., 2016). Conversely, Bonamia exitiosa was initially reported in New Zealand (Ostrea chilensis) and Australia (Ostrea angasi) in the 80's (Corbeil et al., 2006b; Dinamani et al., 1987; Hine et al., 2001). It has been then detected in the USA (Crassostrea ariakensis) (Burreson et al., 2004) and in Europe since 2007 (Abollo et al., 2008). Co-infections with B. ostreae and B. exitiosa can occur in area of high prevalence (Ramilo et al., 2014; Lane et al., 2016). Another Bonamia species, Bonamia perspora, has been characterized in the flat oyster Ostreola equestris in North Carolina, USA (Carnegie et al., 2006).

Although bonamiosis and marteiliosis are endemic in Europe, some countries or zones are still free of Bonamia ostreae, B. exitiosa and/or Marteilia refringens, and surveillance effort is required to prevent diseases introduction into those areas. These protozoan parasites are listed as notifiable pathogens at the European level (EU directive 2006/88, EU implementing regulation 2018/1882) and at the International level (OIE Aquatic Animal Health Code 2019). 
The flat oyster Ostrea edulis is the native European oyster species. Overfishing combined with diseases, notably marteiliosis and bonamiosis, resulted in an important decrease of flat oyster production as well as the decline of wild populations in Europe. This species is now classified as endangered all over Europe (OSPAR agreement 2008-6). Because of its importance for the marine ecosystem, there is a growing interest in restoring flat oyster' populations (Native Oyster Restoration Alliance, https://noraeurope.eu). Moreover, considering the mass mortality events affecting the predominantly farmed oyster species in Europe, the Pacific oyster Crassostrea gigas (EFSA, 2010), the flat oyster is an interesting candidate species for production diversification. Reviving flat oyster populations requires an efficient monitoring of diseases, including proper diagnostic tools. Histology and cytology are the traditional techniques used for the detection of Marteilia spp. and Bonamia spp. parasites, but do not allow species discrimination or the detection of low infections.

Several conventional PCR assays are available for the detection of the genus Marteilia (Le Roux et al., 1999; Lopez-Flores et al., 2004) or M. refringens (Le Roux et al., 2001), and real-time Taqman ${ }^{\circledR}$ PCR assays were recently developed to rapidly detect and type $M$. refringens (Carrasco et al., 2017)(EURL for mollusc diseases unpublished results https://www.eurl-mollusc.eu/SOPs). An even wider choice of PCR assays is available for the detection of parasites of the genus Bonamia and includes conventional and real-time PCR for the detection at the genus level (Carnegie et al., 2000; Cochennec et al., 2000; Corbeil et al., 2006a; Diggles et al., 2003; Marty et al., 2006) and real-time SYBR-Green PCRs for the specific detection of B. ostreae alone (Robert et al., 2009) and for the detection and discrimination of B. ostreae and B. exitiosa (Ramilo et al., 2013).

Although a broad range of PCR assays have been already developed, these tools have not been formally validated according to the OIE recommendations, or partly (Buss et al., 2019; Ramillo et 
al., 2013). In order to facilitate the diagnosis of marteiliosis and bonamiosis, we have developed and validated a new multiplex $\operatorname{Taqman}^{\circledR} \mathrm{PCR}$ assay allowing the detection of regulated pathogens of flats oysters in one step. This new assay was designed to target the $18 \mathrm{~S}$ rDNA gene of $M$. refringens and Bonamia sp. It is intended to be used to monitor parasite prevalence and where relevant to demonstrate freedom from infection in flat oyster populations.

Performance of the new PCR assay were assessed following the 3-stages validation pathway recommended by the OIE (Manual of Diagnostic Tests for Aquatic animals, 2019), which consists in the assessment of 1 -analytical characteristics, 2-diagnostic characteristics, and 3-reproducibility through Inter Laboratory Comparison test. This manuscript attempts to report all key elements of the PCR evaluation according to the STRADAS-aquatic guidelines (Gardner et al., 2016).

\section{MATERIALS AND METHODS}

\section{Field samples}

Flat oyster samples used to assess diagnostic performances of the new PCR assay were collected outside of mortality events between 2011 and 2014 in three main production sites in Brittany, France (Bay of Brest, Bay of Cancale and Golfe du Morbihan). Flat oysters were screened using conventional PCR assays (protocol described in the "conventional PCRs" section below) in the context of a surveillance programme aiming at monitoring the prevalence of $M$. refringens and $B$. ostreae in France.

As Bonamia exitiosa is absent from the 3 previous sampling sites, the new PCR was tested on an additional set of 32 samples collected in the Mediterranean sea off the city of Sète (south of France), where $B$. exitiosa has been reported associated with mortalities. 
Collected oysters were stored frozen before DNA extraction. Samples used to assess diagnostic performances are detailed in Table S1.

\section{Plasmids}

pUC57 plasmids containing the PCR targeted sequences of Marteilia refringens

(5'ACGATCAAAGTGAGCTCGTGCTCGATGGTTTTGCATGGAATCGTGGAACGGGGCCGGCGTTCTGTACTT

CGAGAGCGCTGGCGACGATCAACGGGAGCGATCAGGGGTGAGGGAACTG- 3') and Bonamia sp. (5'-

CAGGATGCCCTTAGATGCTCTGGGCTGCACGCGCGCTACAATGGTGCGTTCAACGAGTTTGACCCGGCTTG ACAAGGCCGGGTAATCTTCAACGCGCACCCAAGTTGGGATAGATGATTGCAATTGTTCATCTTGAACAAGG AATATCTAGTAAACGCAAGTCATCAACTTGCATTGATTACGTCCCTGCCCTTTGTAC-3') were ordered from the "gene synthesis" service of Eurogentec France.

\section{DNA extraction}

Between 20 and $25 \mathrm{mg}$ of gills and digestive gland tissues were collected from each oyster. DNA was extracted using the QiaAmp DNA minikit (Qiagen) following manufacturer's instructions for tissue protocol. DNA extracts were stored frozen at $-20^{\circ} \mathrm{C}$ between 1 to 6 years before analysis and were diluted to a final concentration of $100 \mathrm{ng} / \mu \mathrm{l}$ for conventional PCR applications, or $5 \mathrm{ng} / \mu \mathrm{l}$ for real-time PCR applications.

\section{Conventional PCR assays}

Conventional PCR amplification of Marteilia refringens was performed using the ITS1 primers (Pr4 \& Pr5) described by Le Roux et al. 2001. PCR reactions contained $1 \mu$ l of DNA sample (at 100 $\mathrm{ng} / \mu \mathrm{l}), 1 \times$ PCR buffer, $2.5 \mathrm{mM} \mathrm{MgCl} 2,0.5 \mathrm{mM}$ of each dNTPs, $1 \mu \mathrm{M}$ of each primers and 2.5 unit of Taq polymerase (Goldstar, Eurogentec) in a total volume of $50 \mu \mathrm{l}$. PCR amplifications were carried 
out in a thermocycler (PTC-100 MJ Research) as follows: initial denaturation at $95^{\circ} \mathrm{C}$ for 10 minutes followed by 30 cycles $\left(1 \mathrm{~min}\right.$ et $94^{\circ} \mathrm{C}, 1 \mathrm{~min}$ at $55^{\circ} \mathrm{C}, 1 \mathrm{~min}$ at $72^{\circ} \mathrm{C}$ ) and a final elongation at $72^{\circ} \mathrm{C}$ for 10 minutes.

Conventional PCR amplification of Bonamia sp. was performed using the $18 \mathrm{~S}$ primers (BO and BOAS primers) described by Cochennec et al. (2000). PCR reactions contained $1 \mu$ of DNA sample (at $100 \mathrm{ng} / \mu \mathrm{l}$ ), $1 \times \mathrm{PCR}$ buffer, $1.25 \mathrm{mM} \mathrm{MgCl} 2,0.5 \mathrm{mM}$ of each dNTPs, $1 \mu \mathrm{M}$ of each primers and 2.5 unit of Taq polymerase (Goldstar, Eurogentec) in a total volume of $50 \mu \mathrm{l}$. PCR amplifications were carried out in a thermocycler (PTC-100 MJ Research) as follows: initial denaturation at $95^{\circ} \mathrm{C}$ for 5 minutes followed by 30 cycles $\left(1 \mathrm{~min}\right.$ et $94^{\circ} \mathrm{C}, 1 \mathrm{~min}$ at $55^{\circ} \mathrm{C}, 1 \mathrm{~min}$ at $72^{\circ} \mathrm{C}$ ) and a final elongation at $72^{\circ} \mathrm{C}$ for 10 minutes. Samples were considered positive when a band was observed on agarose gel at $412 \mathrm{bp}$ for M. refringens and $304 \mathrm{bp}$ for Bonamia sp.

\section{New multiplex real-time PCR assay}

Two pairs of primers and probes were designed on the 18S rDNA to specifically amplify Marteilia refringens (Mar-18S primers and probe) and Bonamia sp. including Bonamia ostreae \& Bonamia exitiosa (Bosp2-18S primers and probe) (Table 1).

PCR reactions were performed in a $25 \mu \mathrm{l}$ final volume containing $5 \mu \mathrm{l}$ of DNA samples (at $5 \mathrm{ng} / \mu \mathrm{l})$, 1X PCR Master Mix (Brillant III Ultra-Fast, Agilent Technologies ${ }^{\circledR}$ ref: \# 600881), $0.4 \mu \mathrm{M}$ Mar-18-F primer, $0.4 \mu \mathrm{M}$ Mar-18S-R primer, $0.3 \mu \mathrm{M}$ Mar-18S-IN probe, $0.3 \mu \mathrm{M}$ Bosp2-18S-F primer, $0.5 \mu \mathrm{M}$ Bosp2-18S-R primer, $0.3 \mu \mathrm{M}$ Bosp2-18S-IN probe. PCR amplifications were carried out in the Mx3000 thermocycler (Stratagene ${ }^{\circledR}$ ) as follows: initial denaturation at $95^{\circ} \mathrm{C}$ for 3 minutes followed by 40 cycles at $95^{\circ} \mathrm{C}$ for 15 secondes and $60^{\circ} \mathrm{C}$ for 1 minute. Samples were tested in duplicates and considered as positive when an expected amplification curve was observed in both replicates with $\mathrm{Ct}$ values below the Ct cut-off. Based on the $\mathrm{Ct}$ values obtained at the limit of detection (Caraguel 
et al., 2011), Ct cut-off values were set-up at 37.5 for M. refringens and 37 for Bonamia sp.. Samples with one $\mathrm{Ct}$ above and one $\mathrm{Ct}$ below the $\mathrm{Ct}$ cut-off value were repeated. In the few cases where repetition could not resolve sample status, samples were considered as negative.

\section{General quality assurance statements}

All laboratory analyses were performed under quality management (ISO/IEC 17025) by experienced technicians that were trained to internal procedures. Quality and concentration of extracted DNA was assessed using a NanoDrop ${ }^{\circledR}$ spectrophotometer (Thermo Fisher Scientific). Several quality controls were systematically used to validate the DNA extraction and the PCR steps. An extraction negative control (no tissue) was included in each extraction run. A PCR negative controls (no DNA) and two PCR positive controls (one for each target) were included in each PCR run. PCR positive controls consisted in DNA from the laboratory collections, extracted from $O$. edulis known to be infected with $M$. refringens and $B$. ostreae or $B$. exitiosa. All quality controls were tested by PCR in duplicates.

\section{In silico specificity}

To assess the specificity of the PCR assays in silico, primers and probe sequences were aligned against the following $18 \mathrm{~S}$ rDNA sequences from the NCBI nucleotide collection: Marteilia refringens type O (AJ250699, AB889893) or isolated from O. edulis (MH304628, MH304629, MH342044 ), Marteilia refringens type M, also named pararefringens (AB889894, MH304630, MH304631, MH304632 ), Marteilia cochillia (AB889895, MH304633, KF278722 ), Marteilia sydneyi (AB823742), Marteilia granula (AB856587), Marteilioides chungmuensis (AB110795), Bonamia ostreae (AF192759, AF262995, DQ312295), Bonamia exitiosa (DQ312295, EU016528), Bonamia sp. 
(AY542903), Bonamia perspora (DQ356000), Haplosporidium nelsoni (X74131), Haplosporidium costale (AF387122), Minchinia mercenariae-like ( KY522823), Minchinia tapetis (AY449710).

\section{Analytical characteristics}

Analytical specificity of the new real-time PCR assay was determined by testing several samples infected with targeted parasites and samples infected with closely related parasites (Table 2). Each sample was tested in triplicates.

Analytical sensitivity (or limit of detection) was established by testing 10 -fold serial dilution of plasmidic DNA ranging from 0.1 to 100,000 copies / $\mu$ l. Three PCR runs containing 8 replicates of each dilution were performed resulting in 24 PCR tests for each dilution. The limit of detection was determined as the last dilution where at least $95 \%$ of the samples tested positive.

To evaluate the potential competition between both targets in case of co-infection, tests were performed on cross-serial dilutions of plasmids ranging from $10-10^{5}$ copies/ $\mu$ l with the highest concentrations of $M$. refringens being mixed with the lowest concentration of Bonamia sp. and inversely (tested combinations $M$. refringens/ Bonamia sp.: $10^{5} / 10 ; 10^{4} / 10^{2} ; 10^{3} / 10^{3} ; 10^{2} / 10^{4}$; $10 / 10^{5}$ copies $\left./ \mu \mathrm{l}\right) ; 10$ copies $/ \mu \mathrm{l}$ corresponding to the limit of detection of the PCR, and $10^{5}$ copies / $\mu$ to the "strongest" positive usually find naturally.

Repeatability and preliminary reproducibility were estimated based on results from the analytical sensitivity experiments, by evaluating within and between assay variations in Ct values of replicates, as described in ISO 5725-2.

\section{Diagnostic characteristics (DSe and DSp)}

Diagnostic performances were assessed by comparing currently recommended conventional PCR assays and the new real-time PCR one on a panel of field samples. Three groups of oysters 
representing different levels of prevalence for each targeted parasite were selected based on historical data (sampling site, age class) and previous conventional PCR results. For Marteilia refringens, 386 samples were selected and included a group of 51 oysters with "high" prevalence (> 50\%), a group of 235 oysters with "low" prevalence (5-10\%) and a group of 100 oysters from a population known to be free of the parasite.

For Bonamia ostreae, 349 samples were analysed and included a group of 45 oysters with "high" prevalence (> 50\%), a group of 101 oysters with "low" prevalence (5-10\%), and a group of 203 with "very low" prevalence $(<5 \%)$, as there is no population of flat oysters known to be free of the parasite in France.

These groups of oysters were analysed retrospectively with the new real-time PCR assay and results were compared with results from conventional PCR assays.

\section{Statistical analysis}

As conventional PCR protocols cannot be considered as "gold standards", the diagnostic sensitivity (DSe) and specificity (DSp) of the PCR assays were assessed through latent class analysis. A Bayesian approach was used, where parameters were estimated by Markov Chain Monte Carlo (MCMC) methods via Gibbs sampling. Analysis was performed as described by Joseph et al. (1995) by adapting the model to 2 methods and 3 populations. To take into account the possible dependence between PCR assays, conditional dependence was modelled using the covariance between methods (Vacek et al., 1985; Dendukuri et al. 2001) within the diseased class. Analysis was performed with non-informative priors (beta distributions $(1,1)$ ) except for the DSe and DSp of the conventional Bonamia sp. PCR for which estimates were available in the literature (Balseiro et al., 2006). Based on published results (Balseiro et al., 2006), beta(8.3, 1.8) priors were used for these two parameters, reflecting $95 \%$ confidence that the DSe and DSp is above $60 \%$ with a mode 
set at $90 \%$. The model was implemented in JAGS within the R statistical software environment using packages rjags. For each targeted pathogen, four Monte-Carlo Markov chains (MCMCs) were run with 15,000 iterations with the first 5,000 iterations discarded as a 'burn-in' and the subsequent 10,000 iterations retained for posterior inference. Se and Sp estimates and their 95\% credibility interval are reported. The model is available in supplementary file S3.

\section{Estimation of reproducibility: Inter Laboratory Comparison study}

The European Union Reference Laboratory for mollusc diseases organized an Inter Laboratory Comparison test (ILC) in 2017, in order to test the competency of National Reference Laboratories regarding the detection of Bonamia sp. and Marteilia refringens in flat oyster (Ostrea edulis) by PCR. On this occasion, participants were also invited to test the new real-time PCR assay on the ILC set of samples. Primers and probes of the new PCR assay were sent to the participants, along with a set of 24 samples of flat oyster tissues. Samples were prepared by aliquoting suspensions of small pieces of digestive glands and gills from flat oysters fixed in ethanol and included 8 negative samples, 8 Marteilia refringens positive samples, and 8 Bonamia ostreae positive samples (Fig. S1). Expected answers were qualitative (detected / not detected). Reference results were established based on historical data and results obtained with different methods including several real-time PCRs and histology for some samples. Percentages of matching results were calculated by comparing reference results and participant's results.

The reproducibility of the new real-time PCR assay was assessed based on the results of 17 participating laboratories by measuring the parameters described by Langton et al. 2002 (Langton et al., 2002): Accordance, Concordance and Odds ratio. Accordance is the percentage of chance to obtain same results for two identical samples tested in the same laboratory; it is a measure of "within laboratory variation". Concordance is the percentage of chance to obtain similar results for 
two identical samples tested by two different laboratories; it is a measure of "between laboratory variation".

\section{RESULTS}

\section{In silico specificity of primers and probes}

Mar-18S primers and probe showed $100 \%$ similarity with all the $18 \mathrm{~S}$ rDNA tested sequences from Marteilia refringens type $O$ and type $M$, but also with some $M$. cochillia sequences. Another $M$. cochillia sequence showed one mismatch (on the Mar-18S-F primer). Two mismatches were noted with Marteilia sydneyi (one on the Mar-18S-F primer and one on the Mar-18S-R primer). Marteilia granula or Marteilioides chungmuensis sequences displayed about 15 mismatches distributed along the probe, the forward and the reverse primers.

Bosp2-18S primers and probe showed $100 \%$ similarity with all the $18 \mathrm{~S}$ rDNA tested sequences from Bonamia ostreae, Bonamia exitiosa and Bonamia perspora. Sequence divergences above 25 $\%$ were observed between the probe sequence and Haplosporidium nelsoni, Haplosporidium costale, Minchinia sp., and Minchinia tapetis 18S rDNA sequences as well as at least 5 mismatches on the primer sequences.

\section{Analytical specificity}

No PCR detection was observed in uninfected flat oysters (O. edulis) and mussels (Mytius edulis and M. galloprovincialis). Marteilia refringens primers and probe were able to detect $M$. refringens type $\mathrm{M}$ and type $\mathrm{O}$ in flat oysters (O. edulis) and in mussels (M. edulis and M. galloprovincialis), but also M. cochillia in cockles (Cerastoderma edule) and M. sydneyi in Sydney rock oysters (Saccostrea glomerata). Those results are consistent with the in silico analysis which showed low sequence 
divergences between Mar-18S primers \& probe and M. cochillia and M. sydneyi $18 \mathrm{~S}$ rDNA. No amplification was observed on samples infected with Marteilioides chungmuensis (Table 2). Bonamia sp. primers were only able to detect B. ostreae and B. exitiosa. Other tested parasites (Haplosporidium nelsoni, Mikrocytos mackini, Mikrocytos sp.) resulted in negative PCR results (Table 2).

\section{Analytical sensitivity (limit of detection).}

The new real-time PCR assay consistently amplified plasmidic DNA over a 5 log range from $10^{5}$ to 10 copies $/ \mu$ l (table 3). The lowest dilution producing consistent positive results was 10 copies of plasmids (or genome equivalent) per $\mu$ for each targeted pathogen.

All tested combinations of mixed plasmids (Bonamia sp. and M. refringens) were correctly detected by the new PCR (data not shown).

\section{Cut-off determination}

The mean Ct value obtained at the limit of detection (10 copies / $\mu$ ) was 37.8 for $M$. refringens and 36.9 for Bonamia sp. Therefore, Ct cut-off was established at 37.5 for M. refringens and 37 for Bonamia sp.

\section{Repeatability and preliminary reproducibility (or within-laboratory precision)}

Repeatability and preliminary reproducibility were assessed based on Ct values from the analytical sensitivity experiments (Table 3). Higher intra-assay variability was observed for Marteilia refringens than for Bonamia sp. amplifications. Intermediate precision varied according to the tested dilution and tended to be higher for smaller DNA concentrations. Variation coefficients of 
the intermediate precision were always below $5 \%$, for each tested dilution (Table 3 ), suggesting a good intra-laboratory precision of the PCR assay.

\section{Diagnostic performances (Diagnostic sensitivity and specificity)}

A representative panel of field samples was analysed with the new real-time PCR assay and currently recommended conventional PCR ones (Le Roux et al., 2001, Cochennec et al., 2000) (Cochennec et al., 2000; Le Roux et al., 2001). Results are presented in Table 4A.

Concerning M. refringens detection, both the conventional (Le Roux et al., 2001) and the new realtime PCR did not yield positive results in oyster samples from the population known to be free of the parasite. The new real-time PCR detected more M. refringens positive samples in the "high" and "low" prevalence groups than the conventional PCR (table 4A).

Concerning Bonamia sp. detection, the new real-time PCR and the conventional PCR (Cochennec et al., 2000) yielded similar results; the conventional protocol detected 3 additional B. ostreae infections in the "high" prevalence group, and the new real-time protocol detected 2 additional $B$. ostreae infections in the "low" prevalence group (table 4A).

Diagnostic sensitivity (DSe) and specificity (DSp) were estimated using Bayesian latent class analysis (table 4B). For the detection of $M$. refringens, the new real-time PCR has an estimated DSe of $87.2 \%$ which is higher than for the conventional PCR (60.7\%), and an estimated Dsp of $98.4 \%$ which is equivalent to the conventional PCR. For the detection of $B$. ostreae, the new real-time PCR has an estimated DSe of $77.5 \%$ which is slightly lower than for the conventional PCR (82.8\%), and an estimated Dsp of $98.4 \%$ which is equivalent to the conventional PCR. 
As Bonamia exitiosa is absent from the three previous sampling sites, an additional set of samples coming from a site where $B$. exitiosa has been detected was tested with the conventional PCR and the new real-time PCR (Table 5).

Results showed $90.6 \%$ of agreement between both methods. Three samples yielded discordant results: two were samples found positive with the new real-time PCR and negative with the conventional PCR, and, conversely, one sample was found positive with the conventional PCR and negative with the new PCR.

\section{Inter Laboratory Comparison Study}

Seventeen laboratories tested a set of 24 samples of flat oyster tissues with the new real-time PCR assay and with their own routine PCR assays (sample preparation detailed in Fig. S1). Results obtained with the new real-time PCR during this Inter Laboratory Comparison study are summarized in Table 6. Participants obtained an average of $98.3 \%$ of matching results for the detection of Marteilia refringens and $96.1 \%$ for the detection of Bonamia sp. with the new realtime PCR. Almost all positive samples (99.3\%) were correctly detected by the new real-time PCR assay. Errors mainly corresponded to negative samples identified as positive, especially for $B$. ostreae (the rate of false positives was $2.2 \%$ for $M$. refringens and $5.5 \%$ for Bonamia sp.).

Method precision of the new real-time PCR was estimated for infected and non-infected samples (Table 7). Global accordance and concordance were very high for both the detection of Marteilia refringens (>95\%) and Bonamia sp. (> 93\%) demonstrating a good repeatability and reproducibility of the new assay. Odds ratios calculated on these data showed a higher degree of "between laboratory variation" for non-infected samples, indicating a lower reproducibility for negative 
samples. In particular, the concordance for the detection of Bonamia sp. was below $90 \%$ on noninfected samples which is explained by the occurrence of false positives in some laboratories.

\section{DISCUSSION}

Microscopic and molecular methods are complementary tools for the surveillance of mollusc diseases. Microscopy allows the detection of a large range of pathogens, in particular protozoan parasites, as well as the observation of tissues lesions, giving information on the general health status of mollusc populations. PCR, and especially real-time PCR, are sensitive tools allowing the rapid detection of a specific pathogen; they are particularly suited for the targeted surveillance of listed pathogens such as Bonamia ostreae, B. exitiosa and Marteilia refringens. Currently, molecular diagnosis of regulated pathogens of flat oysters is still mainly performed using conventional PCR protocols developed in the 2000's (survey performed by the EURL for mollusc diseases in 2017) that were not formally validated. Laboratories are progressively shifting from conventional to real-time PCR which provide several benefits such as a reduced time of analysis, an increased sensitivity and a decreased cross-contamination risk. Multiplex PCR allowing the detection of several pathogens in one reaction are quite uncommon for the diagnosis of mollusc diseases. In this context, we have developed a new real-time PCR assay allowing the detection of both Marteilia sp. and Bonamia sp. parasites in flat oysters in an easy single step. Performances of the new real-time PCR assay were assessed following the validation pathway recommended by the OIE (Manual of Diagnostic Tests for Aquatic animals, 2019).

The new real-time PCR assay was shown to detect both Bonamia ostreae and B. exitiosa and not Haplosporidium nelsoni, Mikrocytos mackini, and Mikrocytos donaxi. In silico analyses suggest that it would probably detect $B$. perspora but not other closely related mollusc parasites belonging to 
the genera Haplosporidium, Minchinia and Mikrocytos. The new PCR assay was demonstrated to detect both Marteilia refringens type $\mathrm{M}$ and type $\mathrm{O}$ in flat oysters $O$. edulis and in mussels Mytilus edulis and Mytilus galloprovinciallis. In tested samples, it also detected M. cochillia, a parasite associated with high mortalities of cockles in Spain since 2012, (Carrasco et al., 2013; Villalba et al., 2014) and M. sydneyi, a parasite causing recurring mass mortalities of Sydney rock oysters in Australia (Perkins and Wolf, 1976). The close proximity of 18S rDNA sequences of those parasite species with M. refringens (Villalba et al., 2014) explains these results. Martelioides chungmuensis was not detected by the new assay and Marteilia granula should not be detected considering the sequence divergence observed on primers and probes sequences. Ostrea edulis is not considered as susceptible to M. cochillia and M. sydneyi, therefore, detection of Marteilia sp. with the new real-time PCR strongly indicate the presence of $M$. refringens. In case of first detection with the new real-time PCR in a new place, further characterisation would be required to specify the parasite species.

The analysis of serial dilutions of plasmidic suspensions showed that the new assay can detect down to 10 copies of each targeted DNA per $\mu$ l. Information on the limit of detection (in copies / $\mu \mathrm{l}$ ) of other M. refringens or Bonamia PCR methods is not available, except for the SYBR Green PCR for the detection of $B$. ostreae (Robert et al., 2009) whose detection limit is also 10 copies / $\mu$ l. Additional experiments with different concentrations of mixed plasmids (Bonamia sp. and $M$. refringens), suggested that the presence of one target would not impact the detection of the other target in case of co-infection. To compare the analytical sensitivity of the new real-time PCR with other existing real-time PCRs, we tested serial dilutions of flat oyster DNA infected with $M$. refringens type $M, M$. refringens type $O, B$. ostreae and $B$. exitiosa with the new real-time PCR, the SYBR Green PCR B. ostreae /B. exitiosa (Ramilo et al., 2013) and the Taqman ${ }^{\circledR}$ PCR M. refringens 
Type M / type O (EURL unpublished results, https://www.eurl-mollusc.eu/SOPs) (data not shown). All real-time PCR assays consistently detected parasites down to 4 log dilutions, and showed no amplification over 5 log dilutions, suggesting similar detection limits.

The new real-time PCR was compared to OIE-recommended conventional PCRs (Cochennec et al., 2000; Le Roux et al., 2001) on a panel of field samples categorised in 3 prevalence groups. Tested oysters were collected outside mortality events with a focus on "low" or "very low" prevalence groups to represent the spectrum of infection when monitoring apparently healthy populations. Compared to the conventional M. refringens PCRs (Le Roux et al., 2001), the new real-time PCR has a higher sensitivity (DSe new PCR: $87.2 \%$, DSe conventional PCR: $60.7 \%$ ) and an equivalent specificity (98-99\%) and should allow a better detection of low Marteilia sp. infections. Compared to the conventional Bonamia sp. PCR (Cochennec et al., 2000), the new real-time PCR has an equivalent sensitivity (77.5-82.8\%) and specificity ((98-99\%). Existing molecular tools for the diagnosis of Marteilia parasites were rarely assessed for their diagnostic sensitivity and specificity, however, some data are available for tools targeting Bonamia parasites. The conventional Bonamia sp. PCR (Cochennec et al., 2000) was compared to histology and cytology on a set of 240 oysters, and showed en estimated sensitivity of $92 \%$ and specificity between $85-90 \%$ (Balseiro et al, 2006). The SYBR Green PCR for the detection of B. ostreae and B. exitiosa (Ramilo et al., 2013) was compared to histology and conventional PCR-RFLP (Cochennec et al., 2000) on a set of flat oyster ( $N=137)$. Estimated sensitivity of the SYBR Green PCR was very high ( $99 \%$ for B. ostreae and $100 \%$ for B. exitiosa), however, estimated specificity was quite low ( $72 \%$ for $B$. ostreae and $77 \%$ for B. exitiosa ). More recently, real-time PCR (Corbeil et al., 2006), histology and cytology were evaluated for their detection of Bonamia sp. in Australian farmed oysters ( $N=400)$ (Buss et al. 2019). Sensitivity and specificity of the real-time PCR was estimated at $69 \%$ and $93 \%$ respectively. 
The new PCR was successfully implemented by 17 laboratories that tested a set of 24 samples of known status in the context of an Inter Laboratory Comparison (ILC) study. Almost all positive samples (99.3\%) were correctly detected by the participants, suggesting a high relative sensitivity of the new assay. Most of incorrect results consisted in false positives for both pathogens; and more particularly B. ostreae, even though the rate of false positives was low $(5.5 \%$ for $B$. ostreae, $2.2 \%$ for $M$. refringens). This observation is in agreement with the $98.4 \%$ DSp obtained for $M$. refringens with the Bayesian model, but suggests that the $98.4 \%$ DSp for $B$. ostreae may be lower when the PCR assay is used by several laboratories. Precision estimates, including accordance (within laboratory precision) and concordance (between laboratories precision), were always above $90 \%$ for both targeted pathogens, demonstrating a very good robustness of the new realtime PCR assay.

In this study, a Ct cut-off approach was used to determine sample status; positive or negative. A Ct above the cut-off value could be a false positive due to contamination or unspecific amplification. However a $\mathrm{Ct}$ above the cut-off value might also be obtained in case of very low infection or reflect the presence of parasites DNA in the environment. Indeed, oysters are filter feeders that could accumulate those environmental DNAs. Therefore test interpretation should differ for diagnosis in endemic areas where the cut off approach is recommended and disease certification for translocation to free zones where late PCR amplification would require more investigation.

\section{CONCLUSION}

We have developed and validated for the first time a real-time PCR assay allowing to simultaneously detect Bonamia sp. and Marteilia sp. in flat oysters Ostrea edulis. This new tool 
should allow reducing the number of analysis to perform to monitor regulated pathogens of flat oysters ( $M$. refringens, $B$. ostreae and B. exitiosa) and represents a much quicker and more costeffective alternative to existing PCRs, with equivalent or better performances. Moreover, interlaboratory comparison showed that the new PCR is robust and easily transferable to other laboratory settings.

It would be particularly useful to monitor the prevalence of both Marteilia and Bonamia parasites in endemic areas and to demonstrate freedom from regulated pathogens in flat oyster populations. 


\section{AKNOWLEDGEMENTS}

This work was financially supported by Ifremer, by EU DG SANTE through the European Reference Laboratory for mollusc diseases, and by DGAL through the National Reference Laboratory for Mollusc Diseases.

Authors thank L. Reddecliff for providing Saccostrea commercialis infected with Marteilia sydneyi, N. Carrasco for providing Cerastoderma edule infected with Marteilia cochillia, N. Itoh for providing Crassostrea gigas infected with Marteiloïdes chungmuensis and G. Meyer for providing Ostrea edulis infected with Mikrocytos mackini.

S. Audic is aslo acknowledged for his assistance on Bayesian latent class analysis.

Authors acknowledge all the laboratories that participated in the Inter Laboratory comparison Study:

Snjezana Zrncic, Croatian Veterinary Institute, Croatia

Lone Madsen, DTU National Veterinary Institute, Denmark

Michael Gubbins, CEFAS, England, UK

Giuseppe Arcangeli,Istituto Zooprofilattico Sperimentale delle Venezie, Italy

Deborah Cheslett and Teresa Morrissey, Marine Institute, Ireland

Céline Garcia and Delphine Serpin, IFREMER, LGPMM, France

Hannah Stagg, Marine Scotland, Science Marine Laboratory, Scotland, UK

Sven Bergmann, Friedrich-Loeffler-Institut, Germany

Dimitris Karagiannis, Directorate of Veterinary Centre of Thessaloniki, Greece

Bojan Adzic, Diagnostic Veterinary Laboratory, Montenegro

Paul Savage, Agri-Food and Biosciences Institute, Northern Ireland

Mihaela Costea, Institute for Diagnosis and Animal Health, Romania

Darja Kusar, Veterinary Faculty, Institute of Microbiology and Parasitology, Slovenia 
Anders Alfjorden and Mats Isaksson, National Veterinary Institute, Sweden

Olga Haenen and Michal Voorbergen,WBVR of Wageningen UR, The Netherlands

Oznur Yazicioglu, Bornova Veterinary Control Institute, Turkey 


\section{References}

Abollo, E., Ramilo, A., Casas, S.M., Comesaña, P., Cao, A., Carballal, M.J., Villalba, A., 2008. First detection of the protozoan parasite Bonamia exitiosa (Haplosporidia) infecting flat oyster Ostrea edulis grown in European waters. Aquaculture 274, 201-207.

Balseiro, P., Montes, A., Ceschia, G., Gestal, C., Novoa, B., Figueras Huerta, A., 2007. Molecular epizootiology of the European Marteilia spp., infecting mussels (Mytilus galloprovincialis and M. edulis) and oysters (Ostrea edulis): an update.

Berthe, F.C., Le Roux, F., Adlard, R.D., Figueras, A., 2004. Marteiliosis in molluscs: a review. Aquatic Living Resources 17, 433-448.

Burreson, E.M., Stokes, N.A., Carnegie, R.B., Bishop, M.J., 2004. Bonamia sp.(Haplosporidia) found in nonnative oysters Crassostrea ariakensis in Bogue Sound, North Carolina. Journal of Aquatic Animal Health 16, 1-9.

Caraguel, C.G., Stryhn, H., Gagné, N., Dohoo, I.R., Hammell, K.L., 2011. Selection of a cutoff value for realtime polymerase chain reaction results to fit a diagnostic purpose: analytical and epidemiologic approaches. Journal of Veterinary Diagnostic Investigation 23, 2-15.

Carnegie, R.B., Barber, B.J., Culloty, S.C., Figueras, A.J., Distel, D.L., 2000. Development of a PCR assay for detection of the oyster pathogen Bonamia ostreae and support for its inclusion in the Haplosporidia. Diseases of Aquatic Organisms 42, 199-206.

Carnegie, R.B., Burreson, E.M., Mike Hine, P., Stokes, N.A., Audemard, C., Bishop, M.J., Peterson, C.H., 2006. Bonamia perspora n. sp.(Haplosporidia), a parasite of the oyster Ostreola equestris, is the first Bonamia species known to produce spores. Journal of Eukaryotic Microbiology 53, 232-245.

Carrasco, N., Hine, P.M., Durfort, M., Andree, K.B., Malchus, N., Lacuesta, B., Gonzalez, M., Roque, A., Rodgers, C., Furones, M.D., 2013. Marteilia cochillia sp nov., a new Marteilia species affecting the edible cockle Cerastoderma edule in European waters. Aquaculture 412, 223-230. 
Carrasco, N., Voorbergen-Laarman, M., Lacuesta, B., Furones, D., Engelsma, M.Y., 2017. Application of a competitive real time PCR for detection of Marteilia refringens genotype " $O$ " and " $M$ " in two geographical locations: The Ebro Delta, Spain and the Rhine-Meuse Delta, the Netherlands. Journal of invertebrate pathology $149,51-55$.

Cochennec, N., Le Roux, F., Berthe, F., Gerard, A., 2000. Detection of Bonamia ostreae based on small subunit ribosomal probe. Journal of Invertebrate Pathology 76, 26-32.

Corbeil, S., Arzul, I., Diggles, B., Heasman, M., Chollet, B., Berthe, F.C.J., Crane, M.S., 2006a. Development of a TaqMan PCR assay for the detection of Bonamia species. Diseases of Aquatic Organisms 71, 75-80. Corbeil, S., Arzul, I., Robert, M., Berthe, F.C., Besnard-Cochennec, N., Crane, M.S.J., 2006b. Molecular characterisation of an Australian isolate of Bonamia exitiosa. Diseases of Aquatic Organisms 71, 81-85. Cranfield, H., Dunn, A., Doonan, I., Michael, K., 2005. Bonamia exitiosa epizootic in Ostrea chilensis from Foveaux Strait, southern New Zealand between 1986 and 1992. ICES Journal of Marine Science 62, 3-13. Diggles, B., Cochennec-Laureau, N., Hine, P., 2003. Comparison of diagnostic techniques for Bonamia exitiosus from flat oysters Ostrea chilensis in New Zealand. Aquaculture 220, 145-156.

Dinamani, P., Hine, P.M., Jones, J.B., 1987. Occurrence and Characteristics of the Hemocyte Parasite Bonamia Sp in the New-Zealand Dredge Oyster Tiostrea-Lutaria. Diseases of Aquatic Organisms 3, 37-44. EFSA Panel on Animal Health and Welfare (AHAW), 2010. Scientific Opinion on the increased mortality events in Pacific oysters, Crassostrea gigas. EFSA Journal 8, 1894.

Friedman, C., McDowell, T., Groff, J., Hollibaugh, J., Manzer, D., Hedrick, R., 1989. Presence of Bonamia ostreae among populations of the European flat oyster, Ostrea edulis Linne. California, USA. J Shellfish Res $8,133-137$.

Gardner, I.A., Whittington, R.J., Caraguel, C.G., Hick, P., Moody, N.J., Corbeil, S., Garver, K.A., Warg, J.V., Arzul, I., Purcell, M.K., 2016. Recommended reporting standards for test accuracy studies of infectious diseases of finfish, amphibians, molluscs and crustaceans: the STRADAS-aquatic checklist. Diseases of aquatic organisms 118, 91-111. 
Grizel, H., Comps, M., Bonami, J.R., F, Cousserans, F, Duthoit J.L., Le Pennec M.A., L., 1974. Recherche sur l'agent de la maladie de la glande digestive de Ostrea edulis Linné. Science et Pêche (0036-8350) (ISTPM), 1974 , N. 240 , P. $7-30240$.

Hine, P.M., Cochennec-Laureau, N., Berthe, F.C.J., 2001. Bonamia exitiosus n. sp (Haplosporidia) infecting flat oysters Ostrea chilensis in New Zealand. Diseases of Aquatic Organisms 47, 63-72.

Hudson, E., Hill, B., 1991. Impact and spread of bonamiasis in the UK. Aquaculture 93, 279-285.

Itoh, N., Yamamoto, T., Kang, H.S., Choi, K.S., Green, T.J., Carrasco, N., Awaji, M., Chow, S., 2014. A Novel Paramyxean Parasite, Marteilia granula sp nov (Cercozoa), from the Digestive Gland of Manila Clam Ruditapes philippinarum in Japan. Fish Pathology 49, 181-193.

Joseph, L., Gyorkos, T.W., Coupal, L., 1995. Bayesian estimation of disease prevalence and the parameters of diagnostic tests in the absence of a gold standard. Am J Epidemiol 141, 263-272.

Kang, H.S., Itoh, N., Limpanont, Y., Lee, H.M., Whang, I., Choi, K.S., 2019. A novel paramyxean parasite, Marteilia tapetis sp. nov. (Cercozoa) infecting the digestive gland of Manila clam Ruditapes philippinarum from the southeast coast of Korea. J Invertebr Pathol 163, 86-93.

Kerr, R., Ward, G.M., Stentiford, G.D., Alfjorden, A., Mortensen, S., Bignell, J.P., Feist, S.W., Villalba, A., Carballal, M.J., Cao, A., Arzul, I., Ryder, D., Bass, D., 2018. Marteilia refringens and Marteilia pararefringens sp nov are distinct parasites of bivalves and have different European distributions. Parasitology 145, 14831492.

Lane, H.S., Webb, S.C., Duncan, J., 2016. Bonamia ostreae in the New Zealand oyster Ostrea chilensis: a new host and geographic record for this haplosporidian parasite. Diseases of Aquatic Organisms 118, 55-63. Langton, S., Chevennement, R., Nagelkerke, N., Lombard, B., 2002. Analysing collaborative trials for qualitative microbiological methods: accordance and concordance. International Journal of Food Microbiology 79, 175-181.

Le Roux, F., Audemard, C., Barnaud, A., Berthe, F., 1999. DNA probes as potential tools for the detection of Marteilia refringens. Marine Biotechnology 1, 588-597. 
Le Roux, F., Lorenzo, G., Peyret, P., Audemard, C., Figueras, A., Vivares, C., Gouy, M., Berthe, F., 2001. Molecular evidence for the existence of two species of Marteilia in Europe. J Eukaryot Microbiol 48, 449454.

Lopez-Flores, I., De La Herran, R., Garrido-Ramos, M.A., Navas, J.I., Ruiz-Rejon, C., Ruiz-Rejon, M., 2004. The molecular diagnosis of Marteilia refringens and differentiation between Marteilia strains infecting oysters and mussels based on the rDNA IGS sequence. Parasitology 129, 411-419.

Lopez-Flores, I., Garrido-Ramos, M.A., de la Herran, R., Ruiz-Rejon, C., Ruiz-Rejon, M., Navas, J.I., $2008 a$. Identification of Marteilia refringens infecting the razor clam Solen marginatus by PCR and in situ hybridization. Molecular and Cellular Probes 22, 151-155.

Lopez-Flores, I., Robles, F., Valencia, J.M., Grau, A., Villalba, A., de la Herran, R., Garrido-Ramos, M.A., RuizRejon, C., Ruiz-Rejon, M., Navas, J.I., 2008b. Detection of Marteilia refringens using nested PCR and in situ hybridisation in Chamelea gallina from the Balearic Islands (Spain). Diseases of Aquatic Organisms 82, 7987.

Marty, G.D., Bower, S.M., Clarke, K.R., Meyer, G., Lowe, G., Osborn, A.L., Chow, E.P., Hannah, H., Byrne, S., Sojonky, K., Robinson, J.H., 2006. Histopathology and a real-time PCR assay for detection of Bonamia ostreae in Ostrea edulis cultured in western Canada. Aquaculture 261, 33-42.

Montes, J., 1990. Development of Bonamia ostreae parasitosis of flat oyster, Ostrea edulis, from Galicia, Northwest Spain, Pathology in marine science. Proceedings of the Third International Colloquium on Pathology in Marine Aquaculture, held in Gloucester Point, Virginia, USA, October 2-6, 1988. Academic Press Inc., pp. 223-227.

OSPAR Convention for the protection of the marine environment of the North-East Atlantic, 2008. OSPAR Commission, London, UK.

Pascual, S., Villalba, A., Abollo, E., Garci, M., Gonzalez, A.F., Nombela, M., Posada, D., Guerra, A., 2010. The mussel Xenostrobus securis: a well-established alien invader in the Ria de Vigo (Spain, NE Atlantic). Biological Invasions 12, 2091-2103. 
Perkins, F.O., Wolf, P.H., 1976. Fine-Structure of Marteilia-Sydneyi Sp-N - Haplosporidan Pathogen of Australian Oysters. Journal of Parasitology 62, 528-538.

Pichot, Y., Comps, M., Tige, G., Grizel, H., Rabouin, M.-A., 1981. Recherches sur Bonamia ostreae gen. n., sp. n., parasite nouveau de l'huitre plate Ostrea edulis. Studies on Bonamia ostreae gen. n., sp. n., a new parasite of the European flat oyster, Ostrea edulis L., Fr]. Rev Trav Inst Pêch Marit 43, 131-140.

Ramilo, A., González, M., Carballal, M.J., Darriba, S., Abollo, E., Villalba, A., 2014. Oyster parasites Bonamia ostreae and B. exitiosa co-occur in Galicia (NW Spain): spatial distribution and infection dynamics. Diseases of aquatic organisms 110, 123-133.

Ramilo, A., Navas, J.I., Villalba, A., Abollo, E., 2013. Species-specific diagnostic assays for Bonamia ostreae and B. exitiosa in European flat oyster Ostrea edulis: conventional, real-time and multiplex PCR. Diseases of Aquatic Organisms 104, 149-161.

Robert, M., Garcia, C., Chollet, B., Lopez-Flores, I., Ferrand, S., Francois, C., Joly, J.P., Arzul, I., 2009.

Molecular detection and quantification of the protozoan Bonamia ostreae in the flat oyster, Ostrea edulis. Molecular and Cellular Probes 23, 264-271.

Ruiz, M., López, C., Lee, R.-S., Rodríguez, R., Darriba, S., 2016. A novel paramyxean parasite, Marteilia octospora n. sp.(Cercozoa) infecting the grooved razor shell clam Solen marginatus from Galicia (NW Spain). Journal of invertebrate pathology $135,34-42$.

Tige, G., Rabouin, M.-a., 1976. Etude d'un lot de moules transférées dans un centre touché par l'épizootie affectant l'huître plate. Proc. I.C.E.S K.

Van Banning, P., 1991. Observations on bonamiasis in the stock of the European flat oyster, Ostrea edulis, in the Netherlands, with special reference to the recent developments in Lake Grevelingen. Aquaculture 93, 205-211.

Villalba, A., Iglesias, D., Ramilo, A., Darriba, S., Parada, J.M., No, E., Abollo, E., Molares, J., Carballal, M.J., 2014. Cockle Cerastoderma edule fishery collapse in the Ria de Arousa (Galicia, NW Spain) associated with the protistan parasite Marteilia cochillia. Diseases of Aquatic Organisms 109, 55-80. 
Villalba, A., Mourelle, S.G., Lopez, M.C., Carballal, M.J., Azevedo, C., 1993. Marteiliasis Affecting Cultured Mussels Mytilus-Galloprovincialis of Galicia (Nw Spain) .1. Etiology, Phases of the Infection, and Temporal and Spatial Variability in Prevalence. Diseases of Aquatic Organisms 16, 61-72. 


\begin{tabular}{lll}
\hline Primers/Probes & Sequences & PCR product size \\
\hline Mar-18S-F & 5' ACGATCAAAGTGAGCTCGTG 3' & \\
Mar-18S-R & 5' CAGTTCCCTCACCCCTGAT 3' & $118 \mathrm{bp}$ \\
Mar18S-IN (probe) & 5' GCATGGAATCGTGGAACGGG 3' (FAM-BHQ-1) & \\
\hline Bosp2-18S-F & 5' CAGGATGCCCTTAGATGCTC 3' & \\
Bosp2-18S-R & 5' GTACAAAGGGCAGGGACGTA 3' & $199 \mathrm{bp}$ \\
Bosp2-18S-IN (probe) & 5' TTGACCCGGCTTGACAAGGC 3' (HEX-BHQ-1) & \\
\hline
\end{tabular}

Table 1: Sequences of the primers and probes of the new real-time PCR assay.

\begin{tabular}{|c|c|c|c|c|}
\hline Host species & Status & Origin & $\begin{array}{l}\text { PCR detection } \\
\text { M. refringens }\end{array}$ & Bonamia sp. \\
\hline Ostrea edulis & Not infected & France & No & No \\
\hline Mytilus edulis & Not infected & France & No & No \\
\hline Mytilus galloprovincialis & Not infected & France & No & No \\
\hline Ostrea edulis & M. refringens type $M$ & France & yes & No \\
\hline Mytilus edulis & M. refringens type $M$ & France & yes & No \\
\hline Mytilus galloprovincialis & M. refringens type $M$ & France & yes & No \\
\hline Ostrea edulis & M. refringens type $O$ & France & yes & No \\
\hline Mytilus edulis & M. refringens type $O$ & France & yes & No \\
\hline Mytilus galloprovincialis & M. refringens type $O$ & France & yes & No \\
\hline Cerastoderma edule & Marteilia cochillia & Spain & yes & No \\
\hline Saccostrea glomerata & Marteilia sydneyi & Australia & yes & No \\
\hline Crassostrea gigas & $\begin{array}{l}\text { Marteilioïdes } \\
\text { chungmuensis }\end{array}$ & Japan & No & No \\
\hline Ostrea edulis & Bonamia ostreae & France & No & yes \\
\hline Ostrea edulis & Bonamia exitiosa & France & No & yes \\
\hline Ostreae edulis & Mikrocytos mackini & Canada, & No & No \\
\hline Crassostrea gigas & Haplosporidium nelsoni & France & No & No \\
\hline Donax trunculus & Mikrocytos donaxi & France & No & No \\
\hline
\end{tabular}

Table 2: Analytical specificity. Samples infected with targeted parasites and other closely related

parasites tested with the new real-time PCR assay.

$\begin{aligned} & \text { Plasmidic DNA } \\ & \text { concentration } \\ & \text { (copies/ } \mu \text { I) }\end{aligned}$
\% of positive results
( $\mathrm{N}$ positive/ $\mathrm{N}$ tested)
Mean Ct value
( $\mathrm{n}=24$ )
Intra assay standard
deviation
Inter assay standard
deviation
Intermediate
precision (IP)
Coefficient of
variation of IP (\%)

Marteilia refringens

\begin{tabular}{llllll}
$10^{5}$ & $10^{4}$ & $10^{3}$ & $10^{2}$ & 10 & 1 \\
\hline \hline $\begin{array}{l}100 \% \\
(24 / 24)\end{array}$ & $\begin{array}{l}100 \% \\
(24 / 24)\end{array}$ & $\begin{array}{l}100 \% \\
(24 / 24)\end{array}$ & $\begin{array}{l}100 \% \\
(24 / 24)\end{array}$ & $\begin{array}{l}96 \% \\
(23 / 24)\end{array}$ & $\begin{array}{l}21 \% \\
(5 / 24)\end{array}$ \\
\hline 24.71 & 28.31 & 31.53 & 34.95 & 37.81 & NA \\
\hline 0.93 & 0.71 & 1.24 & 1.33 & 0.59 & NA \\
\hline 0.00 & 0.44 & 0.00 & 0.80 & 0.91 & NA \\
\hline 0.93 & 0.83 & 1.24 & 1.55 & 1.08 & NA \\
\hline 3.77 & 2.95 & 3.93 & 4.44 & 2.87 & NA \\
\hline
\end{tabular}

Bonamia sp.

\begin{tabular}{llllll}
$10^{5}$ & $10^{4}$ & $10^{3}$ & $10^{2}$ & 10 & 1 \\
\hline \hline $\begin{array}{l}100 \% \\
(24 / 24)\end{array}$ & $\begin{array}{l}100 \% \\
(24 / 24)\end{array}$ & $\begin{array}{l}100 \% \\
(24 / 24)\end{array}$ & $\begin{array}{l}100 \% \\
(24 / 24)\end{array}$ & $\begin{array}{l}96 \% \\
(23 / 24)\end{array}$ & $\begin{array}{l}25 \% \\
(6 / 24)\end{array}$ \\
\hline 22.01 & 25.62 & 29.42 & 33.03 & 36.86 & NA \\
\hline 0.27 & 0.51 & 0.86 & 0.84 & 1.00 & NA \\
\hline 0.65 & 0.55 & 0.37 & 0.29 & 0.54 & NA \\
\hline 0.70 & 0.75 & 0.93 & 0.89 & 1.14 & NA \\
\hline 3.19 & 2.93 & 3.17 & 2.70 & 3.08 & NA \\
\hline
\end{tabular}


Table 3: Analytical sensitivity, repeatability and preliminary reproducibility. 10-fold serial dilutions of plasmidic DNA were tested in 8 replicates $\times 3$ PCR runs ( $N=24$ PCR tests for each dilution).

Repeatability and preliminary reproducibility were assed based on the Ct values of the 24 replicates tested for each dilution. Parameters were calculated according to ISO 5725-2.

\section{A}

\begin{tabular}{cccc}
\multicolumn{4}{c}{ Marteilia refringens } \\
\hline \hline & New PCR & Conv.PCR & $\mathrm{N}$ \\
\hline "High" & - & - & 10 \\
prevalence & - & + & 1 \\
group & + & - & 12 \\
(N=51) & + & + & 28 \\
\hline "Low" & - & - & 215 \\
prevalence & - & + & 0 \\
group & + & - & 11 \\
(N=235) & + & + & 9 \\
\hline "Parasite & - & - & 100 \\
free" group & - & + & 0 \\
(N=100) & + & - & 0 \\
& + & + & 0 \\
\hline
\end{tabular}

4.B

M. refringens

\begin{tabular}{ccc} 
& DSe & DSp \\
\cline { 2 - 3 } New PCR & $87.2 \%$ & $98.4 \%$ \\
& {$[70.9-99.4]$} & {$[95.8-99.9]$} \\
Conv. PCR & $60.7 \%$ & $99.7 \%$ \\
& {$[44.6-78.3]$} & {$[99.8-99.9]$}
\end{tabular}

\begin{tabular}{cccc}
\multicolumn{4}{c}{ Bonamia ostreae } \\
\hline \hline & New PCR & Conv. PCR & $\mathrm{N}$ \\
\hline "High" & - & - & 18 \\
prevalence & - & + & 3 \\
group & + & - & 0 \\
(N=45) & + & + & 24 \\
\hline "Low" & - & - & 88 \\
prevalence & - & + & 0 \\
group & + & - & 2 \\
$(\mathrm{~N}=101)$ & + & + & 11 \\
\hline & - & - & 198 \\
"Very low" & - & + & 2 \\
group & - & - & 2 \\
$(\mathrm{~N}=203)$ & + & + & 1 \\
& + & &
\end{tabular}

B. ostreae

\begin{tabular}{ccc} 
& DSe & DSp \\
\cline { 2 - 3 } New PCR & $77.5 \%$ & $98.4 \%$ \\
& {$[55.1-96.0]$} & {$[96.6-99.6]$} \\
Conv. PCR & $82.8 \%$ & $98.7 \%$ \\
& {$[60.1-97.8]$} & {$[97.1-99.7]$}
\end{tabular}

Table 4: 4A - Results obtained with the new real-time PCR and conventional PCR on three groups of flat oysters collected on the field, in B. ostreae and / or M. refringens endemic areas. Left: Results for the detection of Marteilia refringens with the new real-time PCR and the conventional PCR developed by Le Roux et al. 2001 (Le Roux et al., 2001) Right: Results for the detection of Bonamia sp with the new real-time PCR and the conventional PCR developed by Cochennec et al.2000. 
$4 B$ - Diagnostic sensitivity (DSe) and specificity (DSp) of the new real-time PCR and conventional PCR assays estimated by Bayesian latent class analysis. 95\% credibility intervals are indicated in brackets.

\begin{tabular}{ccc}
\multicolumn{3}{c}{ Bonamia exitiosa } \\
\hline \hline New PCR & Conv. PCR & $\mathrm{N}$ \\
\hline- & - & 26 \\
- & + & 2 \\
+ & - & 1 \\
+ & + & 3 \\
\hline
\end{tabular}

Table 5: Results obtained with the new real-time PCR and conventional PCR (Cochennec et al. 2000) (Cochennec et al., 2000) for the detection of Bonamia sp. on the B. exitiosa infected group.

\begin{tabular}{lcc}
\hline & M. refringens detection & Bonamia sp. detection \\
\hline Average \% good results & $98.3 \%$ & $96.1 \%$ \\
\hline Sensitivity & $99.3 \%$ & $99.3 \%$ \\
Rate of false negatives & $0.7 \%$ & $0.7 \%$ \\
\hline Specificity & $97.8 \%$ & $94.5 \%$ \\
Rate of false positives & $2.2 \%$ & $5.5 \%$ \\
\hline
\end{tabular}

Table 6: Synthetic results of the Inter Laboratory comparison study based on results obtained by the 17 participating laboratories on a set of 24 samples ( 8 negative samples, 8 Marteilia refringens positive samples, and 8 Bonamia ostreae positive samples) using the new real-time PCR. Sensitivity is the proportion of samples from known infected samples that tested positive with the new PCR. Rate of false negatives=1-Se. Specificity is the proportion of samples from known uninfected samples that tested negative with the new PCR. Rate of false positives $=1-S p$.

$\underline{\text { Samples }}$

Non infected with Marteilia refringens
Detection of Marteilia refringens

\begin{tabular}{lll}
\hline \hline $\begin{array}{l}\text { Accordance \% } \\
\text { (within laboratory } \\
\text { variation) }\end{array}$ & $\begin{array}{l}\text { Concordance \% } \\
\text { (between laboratory } \\
\text { variation) }\end{array}$ & $\begin{array}{l}\text { Concordance } \\
\text { Odds Ratio } \\
\text { (COR) }\end{array}$ \\
\hline 97.3 & 95.5 & 1.67 \\
\hline
\end{tabular}




\begin{tabular}{llll} 
Infected with Marteilia refringens & 99.0 & 98.0 & 1.00 \\
\cline { 2 - 4 } Global & 97.9 & 96.4 & 1.72
\end{tabular}

\begin{tabular}{|c|c|c|c|}
\hline \multirow[b]{2}{*}{ Samples } & \multicolumn{3}{|c|}{ Detection of Bonamia sp. } \\
\hline & $\begin{array}{l}\text { Accordance \% } \\
\text { (within laboratory } \\
\text { variation) }\end{array}$ & $\begin{array}{l}\text { Concordance \% } \\
\text { (between laboratory } \\
\text { variation) }\end{array}$ & $\begin{array}{l}\text { Concordance } \\
\text { Odds Ratio } \\
\text { (COR) }\end{array}$ \\
\hline Non infected with Bonamia sp. & 94.2 & 89.3 & 1.94 \\
\hline Infected with Bonamia sp. & 99.1 & 98.7 & 1.51 \\
\hline Global & 96.1 & 93.3 & 1.76 \\
\hline
\end{tabular}

Table 7: Method precision: Accordance, Concordance and Concordance Odds Ratio based on the results of 17 laboratories that tested a set of 24 samples of flats oysters with the new real-time $P C R$. 